\title{
Component Composition of Essential Oils Curcuma longa L. (Zingiberaceae) Introduced in Uzbekistan
}

\author{
Dilnoza I. Sotiboldieva ${ }^{1}$, Trobjon X. Mahkamov² \\ ${ }^{1}$ National University of Uzbekistan, Tashkent, Uzbekistan \\ ${ }^{2}$ Institute of Botany, Academy Sciences Republic of Uzbekistan, Tashkent, Uzbekistan \\ Email: ozodbek88@bk.ru
}

How to cite this paper: Sotiboldieva, D.I. and Mahkamov, T.X. (2020) Component Composition of Essential Oils Curcuma longa L. (Zingiberaceae) Introduced in Uzbekistan. American Journal of Plant Sciences, 11, 1247-1253.

https://doi.org/10.4236/ajps.2020.118088

Received: July 7, 2020

Accepted: August 14, 2020

Published: August 17, 2020

Copyright ( 2020 by author(s) and Scientific Research Publishing Inc. This work is licensed under the Creative Commons Attribution International License (CC BY 4.0).

http://creativecommons.org/licenses/by/4.0/

(c) (i) Open Access

\begin{abstract}
This article presents the results of studying the component composition of essential oils of leaves and rhizomes of $C$. longa grown in Uzbekistan. The chemical composition of essential oils of vegetative organs of the Curcuma longa (Zingiberaceae) plant introduced in Uzbekistan was studied for the first time. Essential oils of the plant were isolated by hydrodistillation, their chemical composition was studied by chromatography-mass spectrometry. In the composition of essential oils of leaves and rhizomes $C$. longa L., introduced in the Tashkent oasis, found 27 and 16 components, respectively, among which the leaf is dominated by $\alpha$-fellandren (33.79\%), $\alpha$-terpinolene $(24.28 \%)$, $n$-cymene (12.27\%), eucalyptol (9.77\%), and in the rhizomes-6-(1,3-dimethyl-buta-1,3-dienyl)-1,5,5-trimethyl-7-oxa-bicyclo [4.1.0] hept-2-EN (22.77\%), $\alpha$-curcumene (4.11\%), 2,6,6,9-tetramethyl-tricyclo [5.4.0.0(2.8)] undec-9-EN (3.81\%), $\alpha$-zedren (1.14\%), as well as 3 components that were not identified (the mass spectrum did not match the library data) their mass fraction was $47.47 \%, 10.41 \%$ and $3.46 \%$. The composition of leaves and rhizomes of $C$. longa differ quantitatively and in quality. For example, $\alpha$-curcumene in percentage content is more contained in rhizomes, and $\alpha$-fellandren, which is the dominant content in leaves, is not found in the underground part.
\end{abstract}

\section{Keywords}

Leaf, Rhizomes, Hydrodistillation, Glass Flask, Clevenger Nozzle, Chemical Composition

\section{Introduction}

The search for rational ways to introduce food plants into medical practice and obtain medicines based on them is one of the trends in the development of 
modern medical and pharmaceutical science. The reasons for this trend are, first, the discovery of pharmacological activity for many food plants, and secondly, their low toxicity and the study of almost all possible side effects associated with the fact that food plants have been used by humans for many millennia [1].

The family of Zingiberáceae includes 49 genera and 1300 species of perennial herbaceous plants, of which the most widely used in medical practice are representatives of the genus ginger (up to 90 species), turmeric (80 species), cardamom (7 species). The genus of Curcuma (Curcuma L.) belongs to the division Magnoliophyta, class Liliopsida, subclass Liliidae, superorder Zingiberanae, order Zingiberales, family Zingiberaceae, tribe Hedychieae [2].

\section{Materials and Method}

The object of study was the rhizomes of Curcuma longa L. (Zingiberaceae), brought from Indonesia in 2017 and grown in the Botanical garden of the National University of Uzbekistan.

Essential oils from leaves and rhizomes were obtained by hydrodistillation from air-dry raw materials for 3 hours using a glass flask and a Clevenger attachment. The resulting essential oils from both parts of Curcuma longa L. is a pale yellow mobile liquid with a specific smell. Before analysis, essential oils were stored at $0^{\circ} \mathrm{C}$ in sealed ampoules to preserve the component composition.

The obtained essential oils were analyzed using an Agilent 5975C inert MSD/7890AGC chromatographic mass spectrometer. To separate the components of the mixture, Agilent HP-INNOWax quartz capillary column $(30 \mathrm{~m} \times$ $250 \mu \mathrm{m} \times 0.25 \mu \mathrm{m})$ was used in temperature mode: $50^{\circ} \mathrm{C}(1 \mathrm{~min})-4^{\circ} \mathrm{C} / \mathrm{min}$ to $200^{\circ} \mathrm{C}(6 \mathrm{~min})-15^{\circ} \mathrm{C} / \mathrm{min}$ to $250^{\circ} \mathrm{C}(15 \mathrm{~min})$. The sample was introduced at 1.0 $\mu \mathrm{l}$ (by volume), which the flow rate of the mobile phase was $1.1 \mathrm{ml} / \mathrm{min}$.

The temperature of the injector is $220^{\circ} \mathrm{C}$. EI-MS spectra were obtained in the $\mathrm{m} / \mathrm{z}$ range of $10-550 \mathrm{AU}$. the Components were identified by comparing the characteristics of mass spectra with data from electronic libraries (Wiley Registry of Mass Spectral Data-9th Ed., NIST Mass Spectral Library, 2011), and comparing the retention indices $(R I)$ of compounds determined with respect to the retention time of a mixture of $n$-alkanes $\left(\mathrm{C}_{9}-\mathrm{C}_{28}\right)$.

\section{Result and Discussion}

Curcuma longa L., Sp. Pl. 1: 2 (1753) - perennial herbaceous plant from the family of Zingiberaceae (Figure 1). The rhizome is tuberous, almost round, yellowish-gray, up to $4 \mathrm{~cm}$ in diameter, with annular scars from dead leaves. From the apical bud of the rhizome, above-ground shoots are formed. From the lateral buds develop underground, relatively short $(3-10 \mathrm{~cm}$ long and $0.5-1 \mathrm{~cm}$ in diameter) cylindrical shoots. The color of the rhizomes on the outside is yellow-orange to yellow-brown; the fracture is even, reddish-yellow or yellow.

In addition, numerous thin roots extend from the tuberous rhizome. The leaves are elongated-oval, $20-40 \mathrm{~cm}$ long, $6-15 \mathrm{~cm}$ wide, narrowly pointed at 

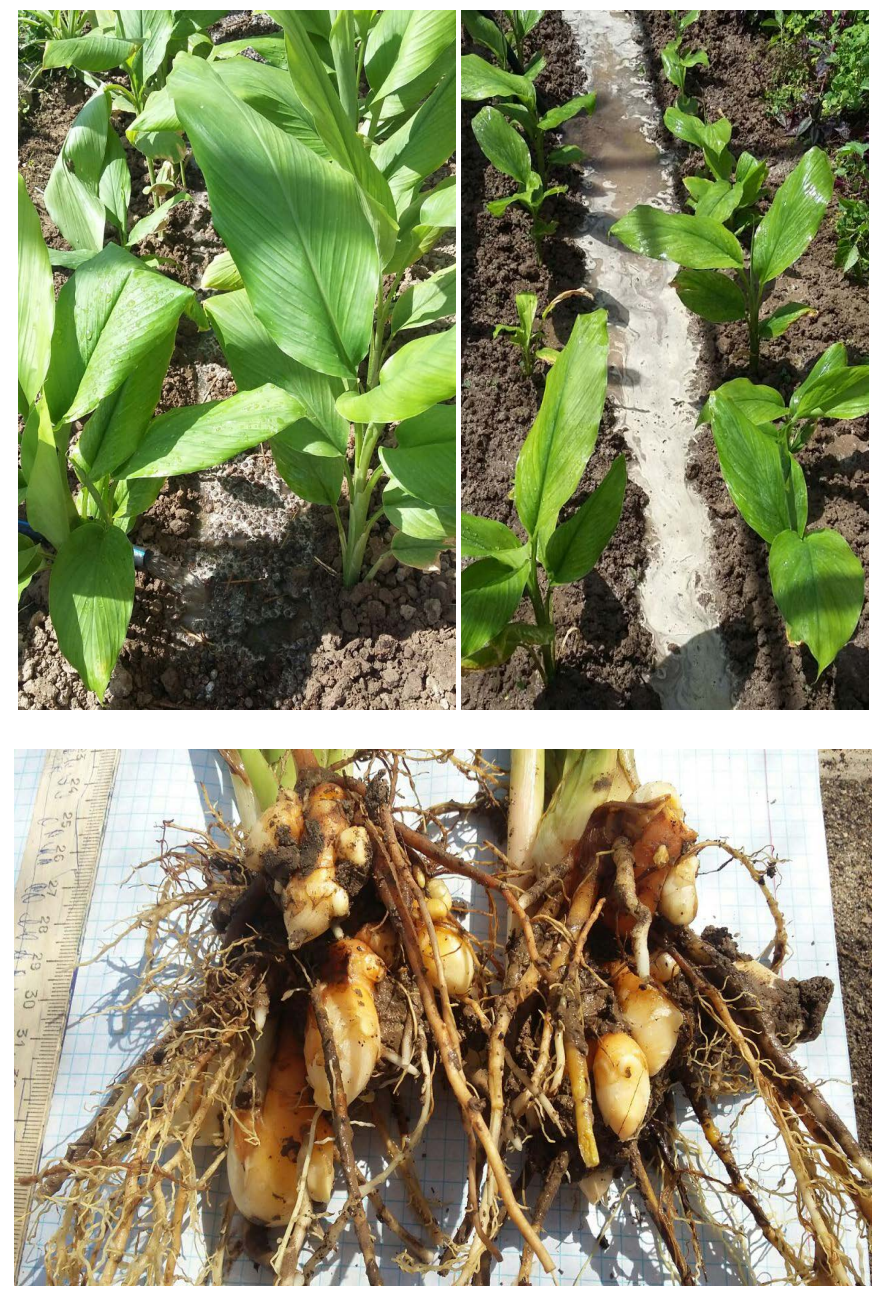

Figure 1. General view of the aboveground and underground parts of C. longa L.

the top; their base gradually turns into a petiole that is the same length as the leaf plate or slightly shorter than it. The peduncle emerges from the leaf sheaths that cover it high. The inflorescence is a cylindrical spike, $10-15 \mathrm{~cm}$ long. Bracts in the lower part of the spike are broadly ovate-rounded, ash-green, in the upper part they are ovate or narrowly ovate, pinkish. The calyx is greenish-white, with three blunt teeth. The corolla tube is $1.5 \mathrm{~cm}$ long, funnel-shaped in the upper part. The petals are yellow. Fruits are filmy globular boxes. It reproduces mainly by rhizome processes [2].

All parts of the plant contain a noticeable amount of essential oil. The rhizomes and stems of many species in this genus contain essential oils and yellow dyes (curcumin) and are cultivated as spices and medicinal plants. The most common spice is turmeric long ( $C$. longa) (other names-turmeric home ( $C$. domestica), turmeric), a powder of dried roots, which is known as the spice turmeric. In countries such as China, India, and Malasia, turmeric has been used as a spice in food since ancient times, as well as in folk medicine [3]. According to foreign researchers, BAS contained in rhizomes have antitumor, 
anti-inflammatory, choleretic, wound-healing effects, etc. [4] [5]. Extracts from turmeric also exhibit analgesic, antioxidant, antiseptic, antispasmodic, dissolving, bactericidal, choleretic effects [6]. Currently, the scientific world's interest in this plant is increasing every year, research is mainly focused on proving the pharmacological activity of turmeric in relation to oncopathology, mental disorders [7].

The main active substances are curcuminoids, and three dominant ones are distinguished from them: curcumin, desmethoxycurcumin and bisdemethoxycurcumin; a certain contribution is made by the terpenoid complex of the plant [8] [9].

The exact geographical origin of turmeric is unknown, but it is safe to assume that it may be South-east Asia [10]. There is no conclusive evidence that C. longa is native to India, although several species of turmeric have been found in India [11]. The greatest variety of turmeric species is found in India, Myanmar, and Thailand [12].

Despite taxonomic research by taxonomists starting with C. Linnaeus, J. Hooker, A. Rendle, T. Valeton, J. Hatchinson, and G. Watt [11] [13] [14] [15] [16] [17], the classification and nomenclature of turmeric remained quite confusing. J. Hooker [14] described turmeric under the natural order Scitamineae and the tribe Zingibereae. However, A. Rendle [15] introduced the subfamily Zingiberoideae in the family Zingiberaceae and described turmeric under the tribe Hedychieae, which was confirmed by J. Hutchinson [17]. It is assumed that the classification of R. Holtum [18] of the family Zingiberaceae is the most authoritative to date, in which it divided the family into two subfamilies, namely Zingiberoideae and Costoideae, and Curcuma was included in the Zingiberoideae as part of the tribe Hedychieae [12].

Rhizomes of Curcuma, which are widely known in Uzbekistan as a spice, are also a valuable source of biologically active compounds (BAC) with a variety of pharmacological activity [5]. The component composition of essential oils of leaves and rhizomes of $C$. longa in Uzbekistan has not been studied. This determines the relevance and novelty of our research.

The purpose of our research is to study the component composition of essential oils of leaves and rhizomes of $C$. longa grown in Uzbekistan.

The results of spectral analysis of the obtained essential oils are shown in $\mathrm{Ta}$ ble 1.

According to the data presented in Table 1 in the composition of essential oils of leaves and rhizomes $C$. longa $\mathrm{L}$., introduced in the Tashkent oasis, found 27 and 16 components, respectively, among which the leaf is dominated by $\alpha$-fellandren (33.79\%), $\alpha$-terpinolene (24.28\%), p-cymene (12.27\%), eucalyptol (9.77\%), and in the rhizomes-6-(1,3-dimethyl-buta-1,3-dienyl)-1,5,5-trimethyl-7-oxa-bicyclo [4.1.0] hept-2-EN (22.77\%), $\alpha$-curcumene (4.11\%),

2,6,6,9-tetramethyl-tricyclo[5.4.0.0(2.8)] undec-9-EN (3.81\%), $\alpha$-zedren (1.14\%), as well as 3 components that were not identified (the mass spectrum did not match the library data), their mass fraction was $47.47 \%, 10.41 \%$ and $3.46 \%$. 
Table 1. Component composition of essential oils of leaves and rhizomes of Curcuma longa L. (1-leaf, 2-rhizomes).

\begin{tabular}{|c|c|c|c|c|c|}
\hline № & The name of the component & $\mathrm{RI}^{*}$ & $\mathrm{RT}^{* *}$ & 1 & 2 \\
\hline 1 & $\beta$-Pinen & 1097 & 3.257 & 0.61 & - \\
\hline 2 & Sabinen & 1108 & 3.472 & 0.45 & - \\
\hline 3 & $(+)$-2-Karen & 1116 & 3.626 & 0.24 & - \\
\hline 4 & 3-Karen & 1131 & 3.927 & 1.47 & - \\
\hline 5 & $\alpha$-Fellandren & 1152 & 4.345 & 33.79 & - \\
\hline 6 & $n$-Mentha-1,4(8)-dien & 1153 & 4.347 & - & 0.05 \\
\hline 7 & $\alpha$-Terpinen & 1161 & 4.505 & 1.68 & - \\
\hline 8 & D-Limonen & 1179 & 4.868 & 3.01 & 0.04 \\
\hline 9 & Evkaliptol (1,8-Sineol) & 1190 & 5.083 & 9.77 & 0.37 \\
\hline 10 & 1,5,5-Trimetil-6-metilen-siklogeksen & 1196 & 5.194 & 0.03 & - \\
\hline 11 & Allosimen & 1218 & 5.686 & 0.18 & - \\
\hline 12 & $\gamma$-Terpinen & 1225 & 5.852 & 1.60 & 0.02 \\
\hline 13 & Kamfen & 1234 & 6.067 & 0.39 & - \\
\hline 14 & $n$-Simen & 1250 & 6.454 & 12.27 & - \\
\hline 15 & $\alpha$-Terpinolen & 1267 & 6.854 & 24.28 & 1.20 \\
\hline 16 & $m$-Simen & 1392 & 10.328 & 0.21 & 0.08 \\
\hline 17 & Digidro- $n$-simen & 1406 & 10.728 & 0.43 & - \\
\hline 18 & 2,3-Dixlopropen & 1410 & 10.834 & - & 0.11 \\
\hline 19 & 4-Metil-3-(1-metiletiliden)-siklogeksen & 1526 & 14.220 & 0.90 & - \\
\hline 20 & $т р а н с$-Kariofillen & 1555 & 15.083 & - & 0.82 \\
\hline 21 & $o$-Simen & 1568 & 15.474 & 0.35 & - \\
\hline 22 & транс- $\alpha$-Bisabolen & 1622 & 17.063 & - & 0.13 \\
\hline 23 & 3-Etil-o-ksilol & 1627 & 17.196 & 0.02 & - \\
\hline 24 & 2-Etil- $M$-ksilol & 1652 & 17.885 & 0.36 & - \\
\hline 25 & $\mathrm{R}(+)$-Limonen & 1664 & 18.223 & 0.63 & - \\
\hline 26 & Bisiklo[4.2.0] okta-1,3,5-tien-7-ol & 1725 & 19.932 & 0.04 & - \\
\hline 27 & $n$-Mentha-1,3,8-trien & 1767 & 21.113 & 0.93 & - \\
\hline 28 & 1,6-Dmetilgepta-1,3,5-триен & 1780 & 21.475 & 0.20 & - \\
\hline 29 & Izopropenil toluol & 1806 & 22.367 & 1.88 & - \\
\hline 30 & $n$-Mentha-1,5,8-trien & 1829 & 23.744 & 0.05 & - \\
\hline 31 & $\alpha$-Sedren & 2013 & 30.245 & - & 1.14 \\
\hline 32 & $\alpha$-Kurkumen & 2017 & 30.963 & 0.85 & 4.11 \\
\hline 33 & Not identified & 2021 & 31.678 & - & 47.47 \\
\hline 34 & Not identified & 2030 & 33.375 & - & 10.41 \\
\hline 35 & 6-(1,3-Dimetil-Buta-1,3-dienil)-1,5,5-trimetil-7-oksa-bisiklo [4.1.0] gept-2-en & 2032 & 33.738 & - & 22.77 \\
\hline 36 & Not identified & 2049 & 36.671 & - & 3.46 \\
\hline \multirow[t]{2}{*}{37} & 2,6,6,9-Tetrametil-trisiklo[5.4.0.0(2,8)] undek-9-en & 2061 & 38.841 & - & 3.81 \\
\hline & $\Sigma$ & & & 96.62 & 95.99 \\
\hline
\end{tabular}

Note: $\mathrm{RI}^{*}$-Kovac Index; $\mathrm{RT}^{* *}$-holding Time. 


\section{Conclusion}

Based on the data, it can be seen that the composition of leaves and rhizomes of C. longa differ quantitatively and in quality. For example, $\alpha$-curcumene in percentage content is more contained in rhizomes, and $\alpha$-fellandren, which is the dominant content in leaves, is not found in the underground part.

\section{Conflicts of Interest}

The authors declare no conflicts of interest regarding the publication of this paper.

\section{References}

[1] Degtyareva, I.I., Skopichenko, S.V. and Skrypnik, I.N. (2000) Justification of the Use of Hepatoprotectors-Antioxidants in the Complex Treatment of Chronic Hepatitis of Various Etiologies. Collection of Science, 9, 64-68.

[2] Cherepanov, S.K. (1995) Vascular Plants of Russia and Neighboring States (within the Former USSR). Mir I Semya, Sankt Petersburg, 992 p.

[3] Schroter, A.I., Valentinov, B.G. and Naumova, E.M. (2002) Natural Raw Materials of Chinese Medicine. Moscow, $415 \mathrm{p}$.

[4] Orlovskaya, T.V. (2011) Pharmacognostic Research of Some Cultivated Plants in Order to Expand Their Use in Pharmacy. Dissertation for the Degree of Doctor of Pharmaceutical Sciences/State Educational Institution of Higher Education, Pyatigorsk State Pharmaceutical Academy, Pyatigorsk, 3-14.

[5] Gupta, S.C., Patchva, S. and Bharat, B. (2013) Therapeutic Roles of Curcumin: Lessons Learned from Clinical Trials. The AAPS Journal, 15, 195-218. https://doi.org/10.1208/s12248-012-9432-8

[6] Sugiyama, Y., Kawakishi, S. and Osawa, T. (1996) Involvement of the $\beta$-Diketone Moiety in the Antioxidative Mechanism of Tetrahydrocurcumin. Biochemical Pharmacology, 52, 519-525. https://doi.org/10.1016/0006-2952(96)00302-4

[7] Gilani, A.H., Shah, A.J., Ghayur, M.N. and Majeed, K. (2005) Pharmacological Basis for the Use of Turmeric in Gastrointestinal and Respiratory Disorders. Life Sciences, 76, 3089-3105. https://doi.org/10.1016/j.lfs.2004.12.021

[8] Berzin, V.B., Katsitadze, L.G., Pilipenko, T.V., Ovcharenko, V.V. and Miroshnikov, A.I. (1996) Identification of Curcumins of Natural Origin. Bioorganic Chemistry, 22, 823-831.

[9] Li, S., Yuan, W., Deng, G., Wang, P., Yang, P. and Bharat, B. (2011) Chemical Composition and Product Quality Control of Turmeric (Curcuma longa L.). Pharmaceutical Crops, 5, 28-54. https://doi.org/10.2174/2210290601102010028

[10] Velayudhan, K.C., Muralidharan, V.K., Amalraj, V.A., Gautam, P.L. and Mandal, S.K. (1999) Curcuma Genetic Resources. Scientific Monograph No. 4, National Bureau of Plant Genetic Resources, New Delhi, 149.

[11] Watt, G.A. (1972) Dictionary of the Economic Products of India. 1908. Periodic. Experts, India, Rep. 1972, 689.

[12] Nair, K.P. (2013) The Agronomy and Economy of Turmeric and Ginger. The Invaluable Medicinal Spice Crops. Elsevier, Amsterdam, $514 \mathrm{c}$.

[13] Linnaeus, C. (1753) Species Plantarum. Ray Society Facsimile, London, 523 p.

[14] Hooker, J.D. (1894) The Flora of British India, Vol. VI. L. Reeve and Co., London, 
792.

[15] Rendle, A.B. (1904) The Classification of Flowering Plants I. Gymnosperms and Monocotyledons. Cambridge University Press, Cambridge, 403. https://doi.org/10.5962/bhl.title.44482

[16] Valeton, T.H. (1918) New Notes on Zingiberaceae of Java and Malaya. Bulletin du Jardin Botanique de Buitenzorg, 2, 1-8.

[17] Hutchinson, J. (1934) Families of Flowering Plants II Monocotyledons. Oxford University Press, London, 243 p.

[18] Holtum, R.E. (1950) The Zingiberaceae of Malay Peninsula. The Gardens' Bulletin Singapore, 13, 1-249. 